\title{
Comparative Analyses of the Teaching Methods and Evaluation Practices in English Subject at Secondary School Certificate (SSC) and General Certificate of Education (GCE O-Level) in Pakistan
}

\author{
DR. Malik Ghulam Behlol (correspondent author) \\ International Islamic University, Islamabd \\ E-mail: ghulam_behlol@yahoo.com \\ Mohammad Anwar \\ International Islamic University, Islamabd
}

\begin{abstract}
The study was conducted to compare the teaching methods and evaluation practices in English subject at secondary school certificate (SSC) and general certificate of education GCE-O -level in Pakistan. The population of the study was students, teachers and experts at SSC and 0- level in the Punjab province. Purposive and random sampling techniques were applied to select the schools and teachers. It was a descriptive study in which the questionnaires were developed to collect the data, and it was analyzed applying $t$ test and chi square. It revealed that GCE- O level results are better due to the availability of competent teachers, educational equipments, management and incentives given to teachers. The examination system also promotes understanding conceptual clarity instead of cramming. It also revealed that the teacher practise Direct, Audio Lingual and activity based methods in GCE -O level system whereas at SSC level system Grammar Translation and Lecture methods were frequently used by the teachers. It was recommended that the steps may be taken from the concerned institutions to design and implement teacher training programme, equip the schools with the modern instructional technology and provision of language based textbooks.
\end{abstract}

Keywords: Methods of Teaching, Examination system, English language, Comparison

\section{Introduction}

Education is the only vital mean for nation-building and progress, key for the solution of problems. It unlocks the doors of prosperity and development. It is the sole source of power to rule over the world. It is a process of preservation and promotion of the intellectual capital that is used to understand and conquer this world. It is imparted through formal, informal and non-formal ways. At formal level, different system of education operates in our country known by the names of English medium public schools, Urdu medium public schools, elite school system (Beacon House, City school system etc. Their curriculum, teaching practices, facilities and equipments and examination system varies from system to system. The results of the Federal Board of Intermediate Education of last three years reveal that the failure ratio of the students in English subject is very high. English is also the medium of instruction at higher level of education and it is also the language of science and technology. The students also face problems at higher level due to lack of command in English language. For this purpose, the researcher decided to conduct a comparative study on the teaching methods and evaluation practices in English subject at secondary school certificate (SSC) and general certificate of education GCE-O -level in Pakistan. The findings of the study are expected to re-motivate the curriculum planners, managers, experts and teachers to bring changes in the English language of Secondary School Curriculum and classroom practices. It would also facilitate the teachers, administrators and educational planners to improve the functioning of the Secondary School Curriculum in English language. The future researchers may also use the finding of this study as a spring board to investigate the quality and provision for English language programmes in Pakistan in the 21 st century.

\section{Objectives of the study}

Major objectives of the study were to:-

1) Compare the teaching methods used by the teachers in Pakistani Secondary School Certificate and British GCE-O level English language programmes

2) Analyze the Evaluation practices of both the systems

3) Compare the academic achievement of graduates of both the programmes.

4) Suggest measures for the improvement of English teaching in secondary schools of Pakistan through indigenous programme. 


\section{Review of literature}

Arabic, Persian and Sanskrit were the medium of instruction before the advent of British in the sub-continent. Lord Macaulay's reform in favour of English language as a medium of instruction in 1835 brought an end to the Oriental languages. The need for English became greater in 1854 when the eligibility to government service was restricted to those who had English education (Mansoor, 1993). Quaid-e-Azam (1947) declared in the first All Pakistan educational conference that Urdu will be the official language, but we cannot ignore the importance of English language. The need and importance of English language has been stressed in the national policies and plans. The National Education Commission (1959) observed that English will continue because it is the only effective means of communication with the world and the most adequate source of information about the latest development in science and technology. Since 1951, the GCE examinations are being conducted at two main levels: Ordinary Level (O level) and Advanced Level (A level) in the United Kingdom. In Pakistan GCE O Level and GCE A Level programmes are offered since 1959. The total number of recognized institutions of Pakistan in the British Council that offer GCE Level programmes is 180.

Naeemullah (2007); Kiyani (2002) conducted a research on comparative analysis of SSC and GCE-O level programme with special reference to science education. The major objectives of the study were to conduct a comparative analysis of policy objective, scheme of studies, curriculum objectives, contents, teaching methods and examination system of Pakistani secondary GCE-O level programme with special reference to Pakistan. The researchers explored through their studies that GCE-A level curriculum development process, curriculum objectives, curriculum contents, teaching methods and examination system were better as compared to Higher Secondary School Certificate (HSSC) in Pakistan. The equipments and the teacher performance are better as compared to SSC level system.

Waheed (2005) conducted A Comparative Study of English Language writing courses meant for teaching writing skills at SSC Level and O levels programmes. The findings of the study indicated that O Level students are good at English in terms of writing skills whereas the courses at SSC Level encourage cramming which is hazardous in the development of writing skills. There is no room for Functional courses that promote understanding and concept based learning at SSC Level programmes.

According to Umbreen (2008), the teachers working in O level system was highly qualified and well experienced but untrained. They prepared lesson plan before presentation of lecture in the classroom to the students and used to encourage questioning in the class in order to build more confidence and better understanding of students. Majority of respondents in the study revealed that the environment of $\mathrm{O}$ and $\mathrm{A}$ level institutions was suitable for teaching and learning. They were satisfied with the facilities provided by the institutions. It was found that in $\mathrm{O}$ and A level system, syllabus was revised according to global trends and the contents were according to the mental level of the students. It was also observed that the books in $\mathrm{O}$ and $\mathrm{A}$ level contain sufficient number of graphs, figures and pictures to explain the concepts. The respondents agreed that policy objectives of $\mathrm{O}$ and $\mathrm{A}$ level curriculum were well formulated. Most of parents and teachers agreed that $\mathrm{O}$ and $\mathrm{A}$ level education system was knowledge based that promotes intellectual development of the students. It was also found that $\mathrm{O}$ and $\mathrm{A}$ level education system promote creativity in the students.

Mansoor (1993) analyzed that the students even after years of learning English as a compulsory subject lacked fluency and faced difficulties in English language usage. A critical look at the English learning situation revealed outdated and inefficient course and teaching methods. The teachers were not trained and there was hardly any interaction between students and the teachers. Receptive and productive skills of learners were ignored due to heavy literary courses. Consequently, same was the case with spoken component. It was not a part of the English syllabus or examinations. The students relied heavily on rote learning and helping books to pass examination.

Shirani (1995) concluded that foreign language classes at SSC level programme were usually too crowded to teach by direct method. It required small class with authentic teaching material. Newspapers, magazines and advertisement were never used due to over concentration on prescribed text books. Over crowded classes restricted teachers from using language teaching techniques such as pair work, group work, situational dialogues and audio visual aids. Level of understanding English of college students was very poor due to in-effective teaching at the secondary level. Consequently students demand their teachers for code-switching to their mother tongue.

Tang (2002) describes in his article that limited and judicious use of the mother tongue in the English classroom does not reduce students' exposure to English but rather assist in the teaching and learning processes. He advocates greater use of L1 in the EFL classroom. He does not agree with the view that the use of mother tongue promotes hindrance in learning of second language. It is hoped that these finding will help to make more people acknowledge in learning second language with the of native language in the foreign language class room. 
According to Safura (2006), majority of the students responded that they were satisfied with the facilities provided by $\mathrm{O}$ and $\mathrm{A}$ level institutions: computer labs, play ground, laborites, cafeterias and libraries. They were also satisfied with the expertise of teachers. They reported that the $\mathrm{O}$ and $\mathrm{A}$ level examinations were based upon understanding of concepts, which developed analytical and conceptual thinking. The flexibility of the examination system developed more interest for students towards education. It was also found that teachers were fair in internal examinations and gave feed back with in a week to the students. It was also analyzed that the merit was strictly followed in all matters relating to the prizes, scholarships, admission and awards given to the students in O level system. Majority of the teachers agreed that in $\mathrm{O}$ and $\mathrm{A}$ level institutions awards, incentives and merits certificate were given to encourage the teachers.

\section{Methodology and Design of the Study}

It was a comparative study in which the researcher focused on comparison of the teaching methods and evaluation practices of Secondary School Certificate (SSC) and General Certificate Education-Ordinary Level (GCE O-level) English language programmes in Pakistan. Therefore, the related literature was reviewed and questionnaires were constructed for data collection. Survey method was used to collect the information to compare the teaching methodology and examination system of secondary and GCE O-level English Language programmes. The researcher collected the opinions from the experts, and teachers of both the systems. The brief procedure of the study is as under:

\subsection{Population}

Population of the study constituted all the experts, teachers and students in the Punjab Province teaching and studying in both of the system of education. The Punjab is administratively divided into eight divisions i.e. Bahawalpur, D.G Khan, Faisalabad, Gujranwala, Lahore, Multan, Rawalpindi and Sargodha. There are 35 districts in all of the eight divisions. The total number of SSC level schools was 4637 with 175480 students (NEC, 2007). There were 180 O-level registered Cambridge institutions, having 250 teachers and 4280 students (The British Council, 2006).

\subsection{Sample}

Simple random sampling and purposive sampling technique was adopted for the selection of the sample of this study. Eight districts were purposively selected out of total 35 districts. The districts included were Bahawalpur, D.G Khan, Faisalabad, Gujranwala, Lahore, Multan, Rawalpindi and Sargodha. These are the divisional headquarters where GCE-O level schools exist enough in number. This technique was adopted because maximum population relating to $\mathrm{O}$ Level institutions existed in the divisional headquarters and sufficient respondents both male and female were available. Simple random sampling technique was applied to select the teachers and experts from the district in both of the system of education. The experts were Headmasters, Principals working in both the systems of education. They were both male and female. The results of the teachers from session 2001 to 2006 were also included for the evaluation of their performance. The detailed sample is as under:

Insert Table 1 Here

\subsection{Delimitation of the Study}

The study was delimited to:

1) only SSC level schools and GCE O level schools in The Punjab province.

2) only teaching methods and examination system of both the systems.

\subsection{Research Instruments}

It was a descriptive study and the questionnaires were constructed to collect the data. Therefore, the researcher developed two questionnaires for teachers and the experts. Literature relating to the development of the questionnaire was reviewed and experts' opinions were obtained to validate the instrument. Reliability of these instruments was determined through Cronbach's alpha as a measure of internal consistency of the items. Cronbach's alpha for experts was 0.89 , for teaches' was 0.86 . For the improvement and modification of research instruments, it was pilot tested. As a result of their opinions 30 items were deleted from the questionnaires and some were modified. The items of the questionnaires were aimed at obtaining information relating to the objectives of the study concerning to the topics such as teaching methods and the examination system applied in both the programmes.

\subsection{Collection and Analysis of Data}

Questionnaires were administered to collect the data of the study. The researcher mailed the questionnaires to experts (selected principals) and teachers of SSC level. Similarly the questionnaires were also mailed to the 
experts (Principals) and teachers of O-level. Seventy five percent of the respondents of the study mailed back the questionnaires. The other required questionnaires were received personally by the researcher. The data were tabulated, analyzed and interpreted in the light of objectives of the study by using t-test, chi square and percentage for comparison of the both systems. Finally, the conclusions were drawn and recommendations were made.

\section{Analysis and Interpretation of Data}

\section{Table 2. Suitability of institutional environment to teach English language}

The table depicts the opinions of the experts about the suitability of the institutional environment to teach English. It indicated that the calculated t-value was found 2.677 at 0.05 level which was greater than the table value. Hence, the statement, "Institutional environment is suitable for English language teaching." is rejected. Moreover mean score of O-level and SSC-level were 3.1 and 2.1. It can be concluded that institutional environment was more suitable to teach English language at O-level as compared to SSC level. The result of the present study has confirmed the findings of the study conducted by Ambreen (2008). Her study indicated that Institutional environment at $\mathrm{O}$ level was suitable to teach English language as compared to SSC level system. It indicates better facilities in O, A level institutions.

\section{Table 3. Appropriateness of teacher student's ratio}

The table illustrates that the teacher student ration in both types of institutions. It revealed that the calculated t-values were found 2.944 and 3.15 at 0.05 levels which were greater than the table value. Hence, the statement, "Teacher student ratio is appropriate." is rejected. Moreover mean score of O-level and SSC-level were 4.2 and 3.15, and according to the views of teachers, it was found 3.54 and 2.19 respectively. It can be concluded that Teacher student ratio is appropriate at O-level as compared to SSC Level. The result of the present study confirmed the findings of the study conducted by Ambreen (2008). Her study indicated that teacher student ratio was appropriate at $\mathrm{O}$ level for English language teaching class. It indicates lack of physical infrastructure and less number of teachers at SSC level institutions.

\section{Table 4. Encouragement of English language teachers by giving awards increments, incentive and merit certificates}

The calculated t-values were found 3.99 and 2.7 at 0.05 levels which were greater than the table value. Hence, the statement, "Award, increments, incentives and merit certificates are given to encourage the English language teachers" is rejected. Moreover mean score of O-level and SSC-level were 3.99 and 2.7. It can be concluded that awards increments, incentives and merit certificates were given to encourage the English language teachers at O-level as compared to SSC level. The result of the present study confirmed the findings of the study conducted by Kiani (2002). His study indicated that awards increments, incentive and merit certificates were given to encourage the English language teachers at $\mathrm{O}$ level system. It reveals that the teachers are not encouraged and motivated at SSC level through the above mentioned incentives.

\section{Table 5. Need of in-service training for the teachers}

The calculated t-values were found 0.23 and 0.156 at 0.05 level which are less than the table value. Hence, the statement, "In service training is needed for all the teachers" is accepted. Moreover mean score of SSC-level and O-level were 4.22 and 4.11, and according to the views of the teachers, it was found 3.44 and 3.26 respectively. It can be concluded that respondents strongly agreed that in-service training was needed for all the teachers at SSC and O-level. The result of the present study confirmed the findings of the study conducted by Naeemullah (2007). The study indicated that in-service training was needed for all the teachers at both SSC and O level.

\section{Table 6. Sufficient number of language activities / tasks in the prescribed books}

The table indicates that the calculated t-values were found 2.44 and 4.99 at 0.05 level which is greater than the table value. Hence, the statement, "There is sufficient number of language activities / tasks in the prescribed books" is rejected. Moreover mean score of O-level and SSC-level were 3.77 and 3.11. It can be concluded that there were sufficient number of language activities / tasks in the prescribed books at O-level as compared to SSC level.

\section{Table 7. Preparation of lesson plans before teaching}

The table indicates that the calculated t-value was found 3.71 at 0.05 level which is greater than the table value. Hence, the statement, "lesson plans are prepared before teaching" is rejected. Moreover mean score of O-level and SSC-level were 4.28 and 3.11. It can be concluded that O-level teachers frequently prepared lesson plans before teaching as compared to SSC-level.

Table 8. Encouragement of questioning during the lesson 
This table reveals that the calculated t-values were found 2.547 and 4.11 at 0.05 level which is greater than the table value. Hence, the statement, "Questioning is encouraged in class." is rejected. Moreover mean score of O-level and SSC-level were 4.11 and 3.22. It can be concluded that questioning was more encouraged in class at O-level as compared to SSC level. The result of the present study confirmed the findings of the study conducted by Ambreen (2008). Her study indicated that questioning was encouraged in class at O level system. It means that proper opportunities are not provided to students to put questions especially at SSC level system.

\section{Table 9. Use of Lecture Method to Teach English language}

This table indicates that the calculated t-value was found 0.624 at 0.05 level which is less than the table value. Hence, the statement, "Lecture method is used to teach English language" is accepted. Moreover mean score of O-level and SSC-level were 2.75 and 2.35. Conclusively, we can say that in the opinion of experts, lecture method was to some extent used to teach English language at O-level system. The result of the present study confirmed the findings of the study conducted by Naeemullah (2007). Their study indicated that the lecture method was to some extent used to teach English language at $\mathrm{O}$ level.

\section{Table 10. Use of Activity Method to teach English language}

This table reflects that the calculated t-value was found 2.439 at 0.05 level which is greater than the table value. Hence, the statement, "Activity method is used to teach English language." is rejected. Moreover, mean score of O-level and SSC-level were 4.59 and 3.52. It can be concluded that activity method was used frequently to teach English language at O-level as compared to SSC level. The result of the present study confirmed the findings of the study conducted by Kaini (2002). This study indicated that the activity method was used to teach English language at O level.

\section{Table 11. Use of Grammar Translation Method to teach English language}

The calculated t-value was found 3.168 at 0.05 level which is greater than the table value. Hence, the statement, "Grammar Translation Method is used to teach English language." is rejected. Moreover mean score of SSC-level and O-level were 2.6 and 3.5. Conclusively we can say that in the opinion of experts Grammar Translation Method was used to teach English language at SSC level as compared to O-level.

\section{Table 12. Use of Direct Method to Teach English language.}

This table depicts that the calculated t-value was found 3.044 at 0.05 level which is greater than the table value. Hence, the statement, "Direct method is used to teach English language" is rejected. Moreover, mean score of O-level and SSC-level were 4.45 and 3.78. It can be concluded that direct method was used to teach English language at O-level as compared to SSC level.

\section{Table 13. Use of Audio Lingual Method to teach English language.}

This table reveals that the calculated $t$-value was found 1.518 at 0.05 level which is less than the table value. Hence, the statement, "Audio lingual method is used to teach English language" is accepted. Moreover, mean score of SSC-level and O-level were 1.71 and 1.45. It can be concluded that audio lingual method was not used to teach English language at SSC and O-level.

\section{Table 14. Use of New Instructional Technology to Teach English language}

This table reflects that the calculated t-values were found to be 3.58 and 3.82 at 0.05 level which is greater than the table value. Hence, the statement, "New instructional technology is properly used to teach English language." is rejected. Moreover, mean score of O-level and SSC-level were 4.57 and 3.73. It can be concluded that new instructional technology was properly used to teach English language at O-level as compared to SSC level. The result of the present study confirmed the findings of the study conducted By Naeemullah (2007). His study indicated that new instructional technology was properly used to teach English language at O-level.

\section{Table 15. Availability of language lab in school}

The table indicates that the calculated t-value was found 1.45 at 0.05 level which is less than the table value. Hence, the statement, "Language lab is available in school" is accepted. Moreover mean score of O-level and SSC-level were 2.59 and 1.79. It can be concluded that Language labs were not available in schools at SSC and O-level.

\section{Table 16. Focus of the examination system on cramming}

The table depicts that the calculated t-values were found 2.845 and 4.818 at 0.05 level which is greater than the table value. Hence, the statement, "The examination system focuses on cramming." is rejected. Moreover, mean score of SSC-level and O-level were 2.75 and 3.61. It can be concluded that examination system at SSC level was geared 
more towards cramming than O-level. The result of the present study confirmed the findings of the study conducted by Bajwa (2007). His study indicated that examination system was more focused on cramming at SSC level.

\section{Table 17. Content validity of English language course covered in Examination}

The table shows that the calculated t-value was found 1.81 at 0.05 level which is less than the table value. Hence, the statement, "Examination covers the whole English language prescribed course" is accepted. Moreover mean score of O-level and SSC-level were 3.99 and 3.82. It can be concluded that the examination system cover the whole English language prescribed course at SSC and O-level.

\section{Table 18. Comparison of SSC and GCE O-level results in English language}

The table shows that results in English subject at O-level was consistently 100\% during the years 2002-2003 to 2006-2007 while at SSC level these were less than $78 \%$ in the sampled institutions. The results of SSC level were $74 \%, 79 \%, 81 \%, 75 \%$ and $78 \%$ during the years 2002-2003, 2003-2003, 2004-2005, 2005-2006 and 2006-2007, respectively. It can be concluded that the results of O-level students were better than the results of SSC level students in the sample institutions.

\section{Conclusions}

The results of English subject of both the systems of the sessions 2001-2002 to 2005-2006 revealed that the academic achievement of both the progammes was different. The result of GCE O-level was better than S.S.C level. It is inferred that the better result is due to the competency of the teachers and better governance and management of the GCE, O level institutions. The result of the sampled years of GCE O level institutions was $100 \%$ whereas the aggregate of the results of the session 2002-2003 to 2006-2007 of the SSC level institutions was $77 \%$. It is concluded the comparatively poor result is due to lack of competency on the part of teachers and language based equipments in schools.

It is also revealed that the teachers get proper encouragement and certification when they present better performance at GCE O level system. There is no such proper and systematic mechanism to reward teachers on better performance at SSC level system. It is a fact that without proper encouragement and incentives, the performance of the teachers cannot be improved. It is instinctive need of the human beings that they need recognition and appreciation of their achievements.

The study reflected that the lecture and grammar translation methods are frequently used at S.S.C level whereas at GCE O-level teachers also follow Activity, Audio-Lingual and Direct Method of language teaching. It is concluded from the findings of the study that the teachers at SSC level are following teacher centered approaches in which the role of the teacher is an authoritative agent in the classroom whereas at GCE O level system, the teachers follow student centered approaches in which the interests and the needs of the students are fully respected.

The views of respondents indicated that examination system of O-level programmes promoted creativity while the examination system of S.S.C level promoted cramming of knowledge. The SSC level examination does not promote comprehension and understanding of the subject. The New instructional technology is neither available in SSC level institutions nor it is properly utilized for the explanation and communication of the concepts.

It is also concluded that the library facilities was available up to the required standard in O-level system and the teachers motivate the students to read the library books. However, the majority of the institutions at SSC Level were without the library facilities, and the teachers did not motivate and encourage the students to study the library books. The language laboratory was completely missing in both of the systems that indicated that we are teaching English without providing practice of listening and speaking skill to our students. The importance of library and language laboratory is recognized fact for developing the language accuracy and fluency of the students. But the institutions of both the system are lacking these facilities.

The number of learning activities in O Level textbooks are greater in number as compared to the learning activities in the textbooks of SSC Level programme. They are well sequenced, properly graded and focus on the basic skills of language learning (listening, speaking, reading and writing). However, the learning activities in the SSC Level textbook were not found in proper sequence to provide practice of the language to the students. It is very difficult to provide the practice of language with out well organized, graded and sufficient language activities.

Teacher student ratio at O-level is appropriate for providing practice of the basic skills of language (1:25). However, the classes at SSC level were found over crowded that did not allow the teacher to conduct pair work, practice sessions and supervise the individualized progress of the students. It is very difficult to learn any language without having sufficient practice of the skills of language.

\subsection{Recommendations}

The recommendations of the study are as under: 
1) The existing environment of the English language classrooms should be transformed as language friendly. The teacher student ratio should be 1:25 so that the teacher may implement student centered approaches properly.

2) Sufficient funds may be allocated to the heads of the institutions to equip the schools with language laboratories. Audio visual material for improving the teaching learning process may be provided.

3) The contents of SSC level books may be updated by the experts with activities/tasks for providing language practice to students.

4) The teachers should be trained to implement innovative methods and techniques in the classrooms. They should be funded and facilitated to conduct action research for improving teaching learning process in the subject of English language.

\section{References}

Bahlol, G. (1998). A study to examine the difficulties of teachers in teaching English to classes IX and X. (Unpublished) M.Ed. thesis, University Arid Agriculture, Rawalpindi: pp.84

Chomsky, N. (1988). Language and Problems of Knowledge. Cambridge Mass MIT Press, London. P. 39.

Government of Pakistan. (1947). Proceedings of the Pakistan Education Conference, Ministry of Interior, (Education Division) Karachi. p. 11.

Government of Pakistan. (1958). The Shariff Commission report on English Ministry of Education Islamabad.

Government of Pakistan. (1959). Report of the commission on National Education, Ministry of Education Karachi.

Kayani, M. (2002). A comparative Study of Secondary and GCE O level Science Education Programme in Pakistan. (Unpublished) Ph.D Thesis, University of Arid Agriculture Rawalpindi, Pakistan.

Mansoor, S. (1993). Punjabi, Urdu, English in Pakistan. Vanguard Book Pvt., Ltd., Lahore. P. 8, 159.

Naeemullah, M. (2007). Comparative study of curricula, teaching methodology and examination system of GCE (A-level) and F.Sc level in Basic Sciences. (Unpublished) Ph.D Thesis University of Arid Agricultural Rawalpindi Pakistan).

Safura, F. (2006). Motivation for Learning English Language at Secondary Level. (Unpublished) M.A TEFL Thesis Allama Iqbal Open University Islamabad Pakistan.

Shirani, M. R. (1995). Utility of direct method for the development of language teaching. (Unpublished) M.A. TEFL, thesis, AIOU, Islamabad: 24pp.

Tang, J. (2002). Teaching Forum 2002. Vol. 40. USA Washington. P.41.

The British Council .(2003). GCE Examination in Pakistan. The British Council, Pakistan. P.7.

The British Council. (2006). Cambridge registered GCE School in Pakistan. www.british.council. Org./pk-exams-cic-centres-list-pdf-27-9-2006.

Umbreen. (2008). A study on social acceptability of "O" and "A" level of education system and its implications in Pakistan. (Unpublished Ph.D Thesis University of Arid Agricultural Rawalpindi Pakistan).

Waheed, A. (2005). .A Comparative Study of English Language writing courses meant for teaching writing skills at metric and O levels. (Unpublished) M.A TEFL Thesis Allama Iqbal Open University Islamabad Pakistan.

Table 1

\begin{tabular}{|l|l|l|l|l|l|l|l|l|}
\hline Districts & $\begin{array}{l}\text { SSC level } \\
\text { Schools }\end{array}$ & $\begin{array}{l}\text { O-level } \\
\text { Schools }\end{array}$ & $\begin{array}{l}\text { SSC Heads } \\
(\mathrm{M})\end{array}$ & $\begin{array}{l}\text { SSC } \\
\text { Heads } \\
(F)\end{array}$ & $\begin{array}{l}\text { O-Heads } \\
(\mathrm{M})\end{array}$ & $\begin{array}{l}\text { O-Heads } \\
(\mathrm{F})\end{array}$ & $\begin{array}{l}\text { SSC } \\
\text { Teachers }\end{array}$ & $\begin{array}{l}\text { O-Teachers } \\
\text { Bahawalpur }\end{array}$ \\
\hline D.G. Khan & 20 & 10 & 3 & 2 & 1 & 1 & 25 & 12 \\
\hline Faisalabad & 20 & 6 & 3 & 2 & 1 & 1 & 25 & 12 \\
\hline Gujranwala & 20 & 10 & 3 & 2 & 1 & 1 & 25 & 12 \\
\hline Lahore & 20 & 6 & 3 & 2 & 1 & 1 & 25 & 12 \\
\hline Multan & 20 & 15 & 3 & 2 & 2 & 2 & 25 & 14 \\
\hline Sargodha & 20 & 6 & 3 & 2 & 1 & 1 & 25 & 12 \\
\hline Rawalpindi & 20 & 15 & 3 & 2 & 1 & 1 & 25 & 12 \\
\hline Total & $\mathbf{1 6 0}$ & $\mathbf{8 0}$ & $\mathbf{2 4}$ & $\mathbf{1 6}$ & $\mathbf{1 0}$ & $\mathbf{1 0}$ & $\mathbf{2 0 0}$ & 14 \\
\hline
\end{tabular}


Table 2. Suitability of institutional environment to teach English language

\begin{tabular}{|l|l|l|l|l|l|}
\hline Respondents & $N$ & Mean & SD & SEm & $T-$ value \\
\hline SSC Level & 40 & 2.9 & 1.19 & \multirow{2}{*}{0.289} & $2.677^{*}$ \\
\hline O-Level & 20 & 3.1 & 1. & \\
\hline
\end{tabular}

$\mathrm{df}=58 \quad$ *Significant at $\mathrm{p}<0.05 \quad$ Table value at $0.05=2.000$

Table 3. Appropriateness of teacher student's ratio

\begin{tabular}{|c|c|c|c|c|c|}
\hline Experts & $N$ & Mean & $S D$ & SEm & $T$-value \\
\hline SSC Level & 40 & 3.15 & 1.21 & \multirow{2}{*}{0.22} & \multirow{2}{*}{$2.944 *$} \\
\hline O-Level & 20 & 4.2 & 0.611 & & \\
\hline Teachers & $N$ & Mean & $S D$ & SEm & $t$-value \\
\hline SSC Level & 160 & 2.9 & 1.51 & \multirow{2}{*}{0.133} & \multirow{2}{*}{$3.15^{*}$} \\
\hline O-Level & 80 & 3.54 & 1.27 & & \\
\hline
\end{tabular}

$\mathrm{df}=58$

$\mathrm{df}=298$
*Significant at $\mathrm{p}<0.05$

*Significant at $\mathrm{p}<0.05$
Table value at $0.05=2.000$

Table value at $0.05=1.960$

Table 4. Encouragement of English language teachers by giving awards increments, incentive and merit certificates

\begin{tabular}{|c|c|c|c|c|c|}
\hline Experts & $N$ & Mean & $S D$ & $S E$ & $t$-value \\
\hline SSC Level & 40 & 2.7 & 1.01 & \multirow{2}{*}{0.258} & \multirow{2}{*}{$3.633^{*}$} \\
\hline O-Level & 20 & 3.99 & 0.99 & & \\
\hline Teachers & $N$ & Mean & $S D$ & SEm & $t$-value \\
\hline SSC Level & 160 & 2.9 & 1.48 & \multirow{2}{*}{0.111} & \multirow{2}{*}{ 2.961* } \\
\hline O-Level & 80 & 3.32 & 1.19 & & \\
\hline
\end{tabular}

$\mathrm{df}=58$

$\mathrm{df}=298$
*Significant at $\mathrm{p}<0.05$

*Significant at $\mathrm{p}<0.05$
Table value at $0.05=2.000$

Table value at $0.05=1.9$

Table 5. Need of in-service training for the teachers

\begin{tabular}{|c|c|c|c|c|c|}
\hline Experts & $N$ & Mean & $S D$ & $S E$ & $T$-value \\
\hline SSC Level & 40 & 4.11 & 0.740 & \multirow{2}{*}{0.201} & \multirow{2}{*}{0.23} \\
\hline O-Level & 20 & 4.22 & 0.455 & & \\
\hline Teachers & $N$ & Mean & $S D$ & SEm & $t$-value \\
\hline SSC Level & 160 & 3.44 & 0.777 & \multirow{2}{*}{0.110} & \multirow{2}{*}{0.156} \\
\hline O-Level & 80 & 3.26 & 1.1 & & \\
\hline
\end{tabular}

$\mathrm{df}=58$

df $=298$

Non-Significant at $p>0.05$

Table value at $0.05=2.000$

Non-Significant at $p>0.05$

Table value at $0.05=1.960$

Table 6. Sufficient number of language activities / tasks in the prescribed books

\begin{tabular}{|l|l|l|l|l|l|l|}
\hline Experts & N & Mean & SD & SEm & \multicolumn{2}{l|}{-value } \\
\hline SSC Level & 40 & 3.11 & 1.52 & \multirow{2}{*}{$2.44^{*}$} \\
\hline O-Level & 20 & 3.77 & 0.56 & SD & SEm & $\mathrm{t}-$ value \\
\hline Teachers & $\mathrm{N}$ & Mean & 1.14 & \multirow{2}{*}{0.13} & \multirow{2}{*}{$3.99 *$} \\
\hline SSC Level & 160 & 2.69 & 1.51 & & \\
\hline O-Level & 80 & 3.31 & &
\end{tabular}

$\mathrm{df}=58 \quad *$ Significant at $\mathrm{p}<0.05 \quad$ Table value at $0.05=2.000$

df $=298 \quad *$ Significant at $\quad \mathrm{p}<0.05 \quad$ Table value at $0.05=1.960$

Table 7. Preparation of lesson plans before teaching

\begin{tabular}{|l|l|l|l|l|l|}
\hline Respondents & $N$ & Mean & SD & SEm & $T$-value \\
\hline SSC Level & 160 & 3.11 & 1.1 & \multirow{2}{*}{0.101} & $3.751^{*}$ \\
\hline O-Level & 80 & 4.28 & 0.74 & & \\
\hline
\end{tabular}

$\mathrm{df}=298 \quad$ *Significant at $\quad \mathrm{p}<0.05 \quad$ Table value at $0.05=1.960$ 
Table 8. Encouragement of questioning during the lesson

\begin{tabular}{|c|c|c|c|c|c|}
\hline Respondents & $N$ & Mean & $S D$ & SEm & $t$-value \\
\hline SSC Level & 40 & 3.22 & 0.53 & \multirow{2}{*}{0.218} & \multirow{2}{*}{$2.547^{*}$} \\
\hline O-Level & 20 & 4.11 & 0.41 & & \\
\hline Respondents & $\mathrm{N}$ & Mean & SD & SEm & $t$ - value \\
\hline SSC Level & 160 & 3.17 & 0.919 & \multirow{2}{*}{0.107} & \multirow{2}{*}{$4.11^{*}$} \\
\hline O-Level & 80 & 4.58 & 8.46 & & \\
\hline
\end{tabular}

$\mathrm{df}=58$

$\mathrm{df}=298$
*Significant at $\mathrm{p}<0.05 \quad$ Table value at $0.05=2.000$

*Significant at $\mathrm{p}<0.05$
Table value at $0.05=1.960$

Table 9. Use of Lecture Method to Teach English language

\begin{tabular}{|l|l|l|l|l|l|}
\hline Respondents & $N$ & Mean & SD & SEm & $t-$ value \\
\hline SSC Level & 40 & 2.35 & 0.611 & \multirow{2}{*}{0.311} & \multirow{2}{*}{0.624} \\
\hline O-Level & 20 & 2.35 & 1.555 & & \\
\hline
\end{tabular}

$\mathrm{df}=58 \quad$ Non-Significant at $\mathrm{p}>0.05$ Table value at $0.05=2.000$

Table 10. Use of Activity Method to teach English language

\begin{tabular}{|l|l|l|l|l|l|}
\hline Respondents & $N$ & Mean & SD & SEm & t-value \\
\hline SSC Level & 40 & 3.52 & 0.728 & \multirow{2}{*}{0.228} & $2.439^{*}$ \\
\hline O-Level & 20 & 4.59 & 0.730 & & \\
\hline
\end{tabular}

$\mathrm{df}=58 \quad *$ Significant at $\mathrm{p}<0.05 \quad$ Table value at $0.05=2.000$

Table 11. Use of Grammar Translation Method to teach English language

\begin{tabular}{|l|l|l|l|l|l|}
\hline Respondents & $N$ & Mean & SD & SEm & $t-$ value \\
\hline SSC Level & 40 & 3.51 & 1.11 & \multirow{2}{*}{0.329} & $3.168^{*}$ \\
\hline O-Level & 20 & 2.6 & 1.75 & & \\
\hline
\end{tabular}

$\mathrm{df}=58 \quad$ *Significant at $\mathrm{p}<0.05 \quad$ Table value at $0.05=2.000$

Table 12. Use of Direct Method to Teach English language.

\begin{tabular}{|l|l|l|l|l|l|}
\hline Respondents & $N$ & Mean & SD & SEm & $t-$ value \\
\hline SSC Level & 40 & 3.78 & 0.639 & \multirow{2}{*}{0.221} & $3.044 *$ \\
\hline O-Level & 20 & 4.45 & 0.62 & \\
\hline
\end{tabular}

Table 13. Use of Audio Lingual Method to teach English language.

\begin{tabular}{|l|l|l|l|l|l|}
\hline Respondents & $N$ & Mean & SD & SEm & $t-$ value \\
\hline SSC Level & 40 & 1.71 & 0.41 & \multirow{2}{*}{0.175} & 1.518 \\
\hline O-Level & 20 & 1.45 & 0.36 & \\
\hline
\end{tabular}

Table 14. Use of New Instructional Technology to Teach English language

\begin{tabular}{|l|l|l|l|l|l|}
\hline Respondents & $N$ & Mean & SD & SEm & $t$-value \\
\hline SSC Level & 40 & 3.73 & 2.1 & \multirow{2}{*}{0.255} & $3.588^{*}$ \\
\hline O-Level & 20 & 4.57 & 0.78 & & \\
\hline Respondents & $\mathrm{N}$ & Mean & SD & SEm & $\mathrm{t}-$ value \\
\hline SSC Level & 160 & 2.63 & 1.24 & \multirow{2}{*}{0.155} & $3.82^{*}$ \\
\hline O-Level & 80 & 3.45 & 1.34 & & \\
\hline
\end{tabular}

$$
\mathrm{df}=58 \quad * \text { Significant at } \mathrm{p}<0.05 \quad \text { Table value at } 0.05=2.000
$$

$\mathrm{df}=298 \quad *$ Significant at $\mathrm{p}<0.05 \quad$ Table value at $0.05=1.960$ 
Table 15. Availability of language lab in school

\begin{tabular}{|l|l|l|l|l|l|}
\hline Respondents & $N$ & Mean & SD & SEm & $t-$ value \\
\hline SSC Level & 160 & 1.79 & 1.41 & 0.13 & \multirow{2}{*}{} \\
\hline O-Level & 80 & 2.59 & 1.23 & & \\
\hline
\end{tabular}

$\mathrm{df}=298 \quad$ Non-Significant at $\quad \mathrm{p}>0.05 \quad$ Table value at $0.05=1.960$

Table 16. Focus of the examination system on cramming

\begin{tabular}{|c|c|c|c|c|c|}
\hline Experts & $N$ & Mean & $S D$ & $S E$ & $t$-value \\
\hline SSC Level & 40 & 3.61 & 0.51 & \multirow{2}{*}{0.246} & \multirow{2}{*}{$2.845^{*}$} \\
\hline O-Level & 20 & 2.75 & 1.53 & & \\
\hline Teachers & $\mathrm{N}$ & Mean & SD & SEm & $\mathrm{t}$ - value \\
\hline SSC Level & 160 & 3.34 & 1.46 & \multirow{2}{*}{0.142} & \multirow{2}{*}{$4.818^{*}$} \\
\hline O-Level & 80 & 2.81 & 1.74 & & \\
\hline
\end{tabular}

$\begin{array}{crrr}\mathrm{df}=58 & \text { *Significant at } \mathrm{p}<0.05 & \text { Table value at } 0.05=2.000 \\ \mathrm{df}=298 & * \text { Significant at } & \mathrm{p}<0.05 & \text { Table value at } 0.05=1.960\end{array}$

Table 17. Content validity of English language course covered in Examination

\begin{tabular}{|l|l|l|l|l|l|}
\hline Respondents & $N$ & Mean & $S D$ & $S E m$ & $t-$ value \\
\hline Level & 160 & 3.82 & 0.68 & \multirow{2}{*}{0.11} & \multirow{2}{*}{1.81} \\
\hline O-Level & 80 & 3.99 & 0.79 & \\
\hline
\end{tabular}

Table 18. Comparison of SSC and GCE O-level results in English language

\begin{tabular}{|l|l|l|l|l|l|l|l|l|l|}
\hline \multirow{2}{*}{ Year } & \multicolumn{9}{|l|}{ SSC } \\
\cline { 2 - 10 } & $\begin{array}{l}\text { Number of } \\
\text { schools }\end{array}$ & $\begin{array}{l}\text { Number of } \\
\text { students } \\
\text { appeared }\end{array}$ & $\begin{array}{l}\text { Number of } \\
\text { students } \\
\text { passed }\end{array}$ & $\begin{array}{l}\text { Pass } \\
\%\end{array}$ & $\begin{array}{l}\text { Number of } \\
\text { schools }\end{array}$ & $\begin{array}{l}\text { Number } \\
\text { students } \\
\text { appeared }\end{array}$ & $\begin{array}{l}\text { Number of } \\
\text { students } \\
\text { passed }\end{array}$ & $\begin{array}{l}\text { Pass } \\
\%\end{array}$ \\
\hline $2002-03$ & 200 & 11715 & 8670 & $74 \%$ & 100 & 678 & 678 & $100 \%$ \\
\hline $2003-04$ & 200 & 12575 & 9935 & $79 \%$ & 100 & 843 & 843 & $100 \%$ \\
\hline $2004-05$ & 200 & 14355 & 11630 & $81 \%$ & 100 & 890 & 890 & $100 \%$ \\
\hline $2005-06$ & 200 & 13640 & 10230 & $75 \%$ & 100 & 1025 & 1025 & $100 \%$ \\
\hline $2006-07$ & 200 & 14640 & 11230 & $78 \%$ & 100 & 1125 & 1125 & $100 \%$ \\
\hline
\end{tabular}

